\title{
Specifičnosti gospodarenja privatnim šumama u zaštićenim područjima s osvrtom na Park prirode Medvednica
}

\author{
Matija Bakarić, Fran Tomašić, Željko Zečić, Karlo Beljan
}

\begin{abstract}
Nacrtak - Abstract
Posljednje desetljeće obilježeno je povećanim zanimanjem privatnih šumovlasnika za gospodarenje svojim šumoposjedom zbog promjena na tržištu drvom uzrokovanih velikim udjelom državnih šuma jer se promjenom načina poslovanja državnoga poduzeća drona industrija okreće prema drugim izvorima sirovine. Tradicionalno gospodarenje privatnom šumom razumijeva pridobivanje drva najčešće neplanski uz degradiranje šumskih staništa. Javne ustanove koje upravljaju pojedinim zaštićenim područjima sve su češće izložene suradnji sa svim dionicima kako bi se zadovoljile želje svih njih u skladu s međunarodnom $i$ nacionalnom legislativom. U uvodnom dijelu rada prikazuju se osnovni podaci o privatnim šumama te problemi u gospodarenju šumama u zaštićenim područjima. U središnjem dijelu rada navode se kategorije zaštite prirode te institucije namijenjene operativnomu gospodarenju privatnim šumama. $U$ rezultatima rada daje se pregled površina privatnih šuma i broja šumoposjednika uz dronu zalihu te popis gospodarskih jedinica unutar Parka prirode Medvednica na temelju pregleda programa gospodarenja. U završnom dijelu prikazuje se moguće unaprjeđenje gospodarenja privatnim šumama na zaštićenim područjima.
\end{abstract}

Ključne riječi: privatne šume, zaštićeno područje, privatni šumoposjednik, NATURA 2000

\section{Uvod - Introduction}

Gospodarenje šumama u Hrvatskoj je pretežito koncentrirano i usmjereno prema šumama $u$ državnom vlasništvu. Ono je stoga obilježeno stalnošću i dosljednošću planiranja i provedbe postupaka i načela održivoga gospodarenja na svim razinama. Nasuprot tomu, privatne su šume zbog povijesnih okolnosti te male zastupljenosti i usitnjenosti bile uvelike zapostavljene sve donedavno (Teslak i dr. 2018).

Šume su obnovljivi prirodni resursi čije su različite mogućnosti korištenja određene stanišnim čimbenicima i dinamikom razvoja šumske vegetacije. Potencijal privatnih šuma u Republici Hrvatskoj sa svojom površinom od 661 720,89 ha (Šumskogospodarska osnova područja Republike Hrvatske 2016.2025.) te veliko prirodno bogatstvo, općekorisne i gospodarske funkcije šuma uvjetuju poseban način planiranja, gospodarenja i korištenja na načelu održivoga gospodarenja šumama, što se očituje u višenamjenskoj ulozi šuma, učinkovitom korištenju resursa te odgovornosti za šume na globalnoj razini (Zakon o šumama, NN 68/2018). Riječ je o površini koja iznosi $24 \%$ od ukupne površine šuma u Republici Hrvatskoj uz drvnu zalihu od $153 \mathrm{~m}^{3} / \mathrm{ha}$ i uz bogatstvo vrstama i razvojnim stadijima, što sve privatne šume čini izuzetno vrijednim prirodnim resursom. Šume uz ostala dobra za koje je zakonom određeno da su od interesa za Republiku Hrvatsku, imaju njezinu osobitu zaštitu (Ustav RH, 2014, članak 52) neovisno o vlasništvu nad njima. Šume i šumska zemljišta zaštićuju se, upotrebljavaju, koriste i njima se gospodari na način određen Zakonom o šumama i posebnim propisima (Zakon o šumama, NN 68/2018).

U suvremenom konceptu održivoga gospodarenja šumama gospodarski oblik šume nije isključivo u prvom planu, već jednako važne postaju i ekološke i socijalne funkcije šuma (Martinić 2019). Unutar zaštićenih područja svih razina zaštite šumska su staništa prepoznata kao prioritet zaštite $\mathrm{u}$ hrvatskim 
i međunarodnim okvirima te kao neodvojiv dio prirodne baštine zaslužuju posebnu pažnju prilikom planiranja korištenja i zaštite zaštićenoga područja.

\section{Gospodarenje privatnim šumama u zaštićenim područjima prirode - Management of private forests in protected nature areas}

Republika Hrvatska kao izrazito šumovita zemlja bogata velikim brojem zaštićenih područja svih kategorija zaštite ima isprepleten odnos zaštićenih područja sa šumama. Velik broj hrvatskih nacionalnih parkova i parkova prirode ima upravo šume i šumske zajednice te njima pripadajuću biološku raznolikost kao ključno obilježje i važan aspekt upravljanja (Tomašić 2018).

Gospodarenje svim prirodnim dobrima na područjima koja uživaju neku vrstu zaštite provodi se na temelju planova gospodarenja prirodnim dobrima u kojima se nalaze smjernice o očuvanju bioraznolikosti, krajobrazne raznolikosti i georaznolikosti, te u kojima se zabranjuju korištenje prirodnih dobara ako uzrokuje oštećivanje površinskih ili podzemnih geoloških, hidrogeoloških i geomorfoloških vrijednosti, narušavanje povoljnoga stanja divljih vrsta ili staništa ili smanjenje bioraznolikosti, krajobrazne raznolikosti i georaznolikosti. Planovi upravljanja prirodnim dobrima sadrže ocjenu prihvatljivosti za ekološku mrežu koju propisuje nadležno ministarstvo.
Prema Zakonu o zaštiti prirode (NN 80/2013) u Republici Hrvatskoj postoji devet kategorija prostorne zaštite koje imaju svaka svoj režim zaštite (tablica 1). Gospodarenje šumama također je ovisno o stupnju zaštite pa je tako najblaži u parku prirode u kojem su dopuštene sve aktivnosti koje su u skladu s programima gospodarenja, sve do strogoga rezervata u kojem su primarne dopuštene aktivnosti očuvanje prirodnoga stanja, znanstveno istraživanje i obrazovanje koje ne mijenja prirodne procese.

Šumama u privatnom vlasništvu gospodari se sukladno Zakonu o šumama i programima gospodarenja za šume šumoposjednika. Gospodarenje privatnim šumama krije mnoge nepoznanice i izazove uz značajan nedostatak relevatnih informacija. Šumske su parcele uglavnom malih površina i dosta udaljene jedne od drugih. Često vlasnici nisu ni svjesni da su u posjedu neke šume, koju su vjerojatno naslijedili, te i ne znaju gdje se ona nalazi. Što se tiče ekonomike gospodarenja privatnim šumama, nepovoljna je okolnost što je njihovo vlasništvo u Hrvatskoj vrlo fragmentirano. U prosjeku svaki vlasnik ima dvije parcele koje nisu povezane. Granice parcela nisu označene i u praksi često ne postoji suglasnost o vlasništvu (Posavec i Beljan 2012).

Kao pomoć šumovlasnicima pri gospodarenju njihovim šumama u Republici Hrvatskoj ističu se dvije institucije:

$\Rightarrow$ Hrvatska poljoprivredno-šumarska savjetodavna služba (HPŠSS)

Tablica 1. Kategorije zaštite prirode prema Zakonu o zaštiti prirode s dopuštenim namjenama

Table 1 Categories of nature protection according to the Law on Nature Protection with permitted purposes

\begin{tabular}{|c|c|}
\hline Kategorija - Category & Namjena - Aim \\
\hline $\begin{array}{l}\text { Strogi rezervat } \\
\text { Strict nature reserve }\end{array}$ & $\begin{array}{l}\text { Znanstvena istraživanja, praćenje stanja prirode, obrazovanje } \\
\text { Scientific research, monitoring the state of nature, education }\end{array}$ \\
\hline $\begin{array}{l}\text { Nacionalni park } \\
\text { National park }\end{array}$ & $\begin{array}{l}\text { Znanstvena, kulturna, odgojno-obrazovna i rekreativna namjena } \\
\text { Scientific, cultural, educational and recreational purposes }\end{array}$ \\
\hline $\begin{array}{l}\text { Posebni rezervat } \\
\text { Special reserve }\end{array}$ & $\begin{array}{l}\text { Zaštita biološke raznolikosti s naglaskom na određenu sastavnicu (fauna, šume, hidrologija i dr.), znanstvena istraživanja, } \\
\text { posjećivanje je moguće } \\
\text { Protection of biological diversity with emphasis on a certain component (fauna, forests, hydrology, etc.), scientific research, } \\
\text { visits are possible }\end{array}$ \\
\hline $\begin{array}{l}\text { Park prirode } \\
\text { Nature park }\end{array}$ & $\begin{array}{l}\text { Zaštita biološke i krajobrazne raznolikosti, odgojno-obrazovna, turističko-rekreacijska namjena } \\
\text { Protection of biological and landscape diversity, educational, tourist-recreational purpose }\end{array}$ \\
\hline $\begin{array}{l}\text { Regionalni park } \\
\text { Regional park }\end{array}$ & $\begin{array}{l}\text { Zaštita krajobrazne raznolikosti, održivi razvitak, turizam } \\
\text { Protection of landscape diversity, sustainable development, tourism }\end{array}$ \\
\hline $\begin{array}{l}\text { Spomenik prirode } \\
\text { Monument of nature }\end{array}$ & $\begin{array}{l}\text { Zaštita prostorno ograničenoga lokaliteta ili reprezentativnoga primjerka, znanstvena, estetska ili odgojno-obrazovna namjena } \\
\text { Protection of a spatially limited locality or a representative specimen, scientific, aesthetic or educational purpose }\end{array}$ \\
\hline $\begin{array}{l}\text { Značajni krajobraz } \\
\text { Significant landscape }\end{array}$ & $\begin{array}{l}\text { Zaštita krajobrazne i biološke raznolikosti, održivi razvitak, turizam, rekreacija } \\
\text { Protection of landscape and biological diversity, sustainable development, tourism, recreation }\end{array}$ \\
\hline $\begin{array}{l}\text { Park-šuma } \\
\text { Forest park } \\
\end{array}$ & $\begin{array}{l}\text { Turizam i rekreacija, zaštita krajobrazne vrijednosti } \\
\text { Tourism and recreation, protection of landscape value }\end{array}$ \\
\hline $\begin{array}{l}\text { Spomenik parkovne arhitekture } \\
\text { Monument of park architecture }\end{array}$ & $\begin{array}{l}\text { Zaštita prirodne i kulturne baštine i krajobrazne raznolikosti, turizam i rekreacija, edukacija } \\
\text { Protection of natural and cultural heritage and landscape diversity, tourism and recreation, education }\end{array}$ \\
\hline
\end{tabular}


$\Rightarrow$ Hrvatski savez udruga privatnih šumovlasnika (HSUPŠ).

Hrvatska poljoprivredno-šumarska savjetodavna služba temeljna je ustanova za pomoć šumoposjednicima pri gospodarenju njihovim šumama. Kao javna ustanova za obavljanje savjetodavnih djelatnosti iz poljoprivrede, šumarstva i ribarstva nadležna je za poslove dijela javnih ovlasti te unapređenje gospodarenja šumama i šumskim zemljištima privatnih šumovlasnika.

Hrvatski savez udruga privatnih šumovlasnika osnovan je 2008. godine kao samostalna, nestranač$\mathrm{ka}$, interesna organizacija dobrovoljno udruženih udruga privatnih šumovlasnika radi zadovoljavanja zajedničkih interesa članova saveza. Glavni je cilj saveza planskim udruživanjem i radom udruga, sudjelovanjem u provedbi projekata iz šumarstva poboljšati kakvoću i gospodarsku vrijednost šumskih proizvoda te unaprijediti gospodarenje privatnim šumama u Republici Hrvatskoj. Savez trenutačno broji 18 udruga članica koje se preko krovnoga HSUPŚ-a bore za prava vlasnika šuma u Republici Hrvatskoj utjecajem na politiku upravljanja privatnim šumama.

Ključnu ulogu u poboljšanju gospodarenja ima Upisnik šumoposjednika koji vodi nadležno ministarstvo radi rješavanja problema u privatnom šumovlasništvu pomoću subvencija i potpora kapitalnim ulaganjima šumoposjednika iz proračuna Republike Hrvatske i drugih izvora sukladno posebnim propisima (Bakarić 2018).

Privatne šume $u$ pojedinoj kategoriji zaštite (tablica 1) šumoposjednicima omogućuju različite načine gospodarenja u ovisnosti o razini zaštite. Ovdje valja napomenuti kako u zaštićenim područjima tradicionalno gospodarenje šumom uz iskorištavanje isključivo drva ne smije biti glavni oblik. Trenutačno potpore EU-a pružaju mogućnost iskorištavanja financijske pomoći i nadoknade za izgubljeni prihod privatnim vlasnicima šuma koji su u svojim šumama voljni provoditi aktivnosti prihvatljive za prirodu (Martinić 2011). Neke od mjera koje se mogu primjenjivati za podršku šumovlasnicima vezanima uz ekološku mrežu NATURA 2000 jesu:

$\Rightarrow$ godišnja potpora po hektaru šume za nadoknadu troškova i izgubljenih prihoda koji su izravna posljedica ograničenja korištenja zbog provedbe obveza iz NATURA 2000
$\Rightarrow$ potpore po hektaru šumske površine za plaćanje dodatnih troškova, onih iznad standardnih troškova za obvezne radove

$\Rightarrow$ pokrivanje troškova za obnovu šumskoga potencijala za šume stradale u prirodnim katastrofama

$\Rightarrow$ potpore za širok spektar ulaganja u neproizvodne vrijednosti šuma, npr. pokrivanje troškova utvrđivanja ekološko-biološkoga i rekreativnoga potencijala šuma ili pokrivanje troškova izrade plana upravljanja za područja NATURA 2000

$\Rightarrow$ Programom ruralnoga razvoja Republike Hrvatske i njegovom mjerom 8 , podmjerom 8.5 . i operacijom 8.5.2. za razdoblje od 2014. do 2020. godine s produljenjem važenja, dodjeljuje se potpora projektima koji omogućuju dostupnost rekreacijske, zdravstvene i turističke funkcije šuma $u$ javne svrhe. Ciljani su korisnici ove mjere privatni šumoposjednici, udruge šumoposjednika, trgovačka društva i druge pravne osobe koje djeluju u smjeru zaštite prirode i okoliša.

\section{Privatne šume u Parku prirode Medvednica - Private forests in Medvednica Nature Park}

Park prirode, kao kategorija zaštićenoga područja, prema Zakonu o zaštiti prirode (NN 80/2013) prostrano je prirodno ili dijelom kultivirano područje kopna $\mathrm{i} /$ ili mora velike bioraznolikosti i/ili georaznolikosti, s vrijednim ekološkim obilježjima, naglašenim krajobraznim i kulturnopovijesnim vrijednostima. Park ima izraženu znanstvenu, kulturnu, odgojno-obrazovnu i rekreacijsku funkciju, a u njem su dopuštene gospodarske i druge djelatnosti koje ne ugrožavaju njegova bitna obilježja i uloge.

U Parku prirode Medvednica šumska su dobra korištena tijekom više stoljeća, samo se s vremenom mijenjao način korištenja i njege šuma. Dobni sastav šumskih zajednica pokazuje da prevladavaju jednodobne šumske sastojine te da je udio starih sastojina vrlo malen.

Parkom prirode (tablica 2) upravlja Javna ustanova »Park prirode Medvednica« koju je 8. 8. 1998. osnovala Vlada Republike Hrvatske (slika 1). 
Tablica 2. Ključni podaci o Parku prirode Medvednica Table 2 Key information about Medvednica Nature Park

\begin{tabular}{|c|c|}
\hline $\begin{array}{l}\text { Površina Parka prirode Medvednica } \\
\text { Area of Medvednica Nature Park }\end{array}$ & 17938 ha \\
\hline Nadmorska visina - Elevation & $\begin{array}{c}120-1035 \mathrm{mnv} \\
120-1035 \text { meters above sea level }\end{array}$ \\
\hline Najviši vrh - Highest peak & Sljeme \\
\hline $\begin{array}{l}\text { Smjer pružanja - Direction of } \\
\text { offering }\end{array}$ & $\begin{array}{c}\text { JZ-SI u dužini } 42 \mathrm{~km}-\mathrm{SW}-N E \text { in } \\
\text { length } 42 \mathrm{~km}\end{array}$ \\
\hline $\begin{array}{l}\text { Teritorijalna razgraničenost - } \\
\text { Territorial demarcation }\end{array}$ & $\begin{array}{c}\text { Krapinsko-zagorska županija, Grad } \\
\text { Zagreb, Zagrebačka županija } \\
\text { Krapina-Zagorje County, City of } \\
\text { Zagreb, Zagreb County }\end{array}$ \\
\hline $\begin{array}{l}\text { Broj naselja teritorijalno čitavih/ } \\
\text { dijelom u Parku prirode - Number } \\
\text { of settlements territorially readable / } \\
\text { partly in the Nature Park }\end{array}$ & \\
\hline Ukupno - Total & 28 \\
\hline $\begin{array}{l}\text { U Gradu Zagrebu - In the City of } \\
\text { Zagreb }\end{array}$ & 4 \\
\hline $\begin{array}{l}\text { U Zagrebačkoj županiji - In Zagreb } \\
\text { County }\end{array}$ & 7 \\
\hline $\begin{array}{l}\text { U Krapinsko-zagorskoj županiji - In } \\
\text { Krapina-Zagorje County }\end{array}$ & 17 \\
\hline $\begin{array}{l}\text { Broj stanovnika na području Parka, } \\
\text { procjena 2001. godine - Population } \\
\text { in the Park area, estimated in } 2001\end{array}$ & $\begin{array}{l}\text { oko } 7400 \\
\text { about } 7400\end{array}$ \\
\hline $\begin{array}{l}\text { Površina pod šumama - Area under } \\
\text { forests }\end{array}$ & 14550 ha, $81 \%$ \\
\hline
\end{tabular}

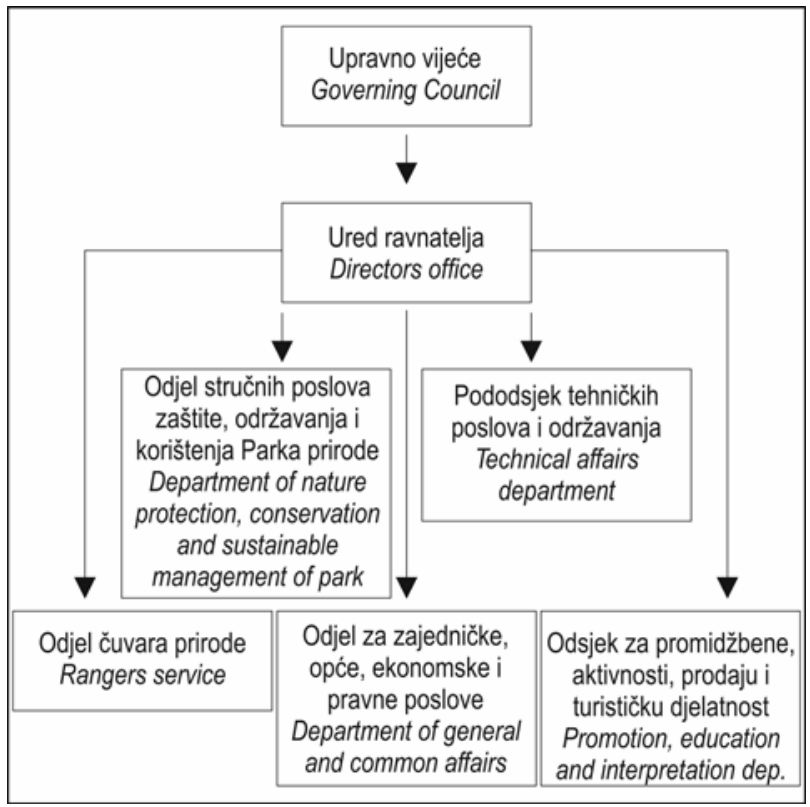

Slika 1. Unutarnje ustrojstvo Parka prirode Medvednica Fig. 1 Internal organization of Medvednica Nature Park

Područje Medvednice podijeljeno je na 11 gospodarskih jedinica ukupne površine 15 548,94 ha, od kojih se neke cijelom površinom nalaze unutar granica Parka, a ostale većim ili manjim dijelom. Unutar parkovnih granica privatne šume zauzimaju površinu od 5775 ha, dok 8775 ha otpada na državne šume (Plan upravljanja Parkom prirode Medvednica). Privatne šume unutar granica Parka zbog neplanskoga su gospodarenja u degradiranom stadiju, što je posljedica nekontroliranoga izvođenja radova pri pridobivanju drva (neuspostavljanje šumskoga reda, zatrpavanje obala i korita potoka trupcima i granama). Zbog toga je potrebno provoditi pojačan nadzor i suradnju s institucijama radi sprečavanja takve loše prakse.

Kako navodi Tomašić (2018), jedan od glavnih uzroka nepoštivanja propisa i teškoća u gospodarenju zasigurno je veličina posjeda, s obzirom na to da na ukupnu površinu šuma od 15 548,94 ha dolazi čak 37619 posjednika, s prosječnom veličinom posjeda manjom od 1 ha, konkretno 0,46 ha. Na slici 2 jasno je uočljiv podatak kako gotovo $84 \%$ šumoposjednika ima posjede veličine do 1 ha, približno 12 $\%$ ih ima posjede veličine $1-5$ ha, a oko $3 \%$ posjede veličine 5 - 10 ha. Ostalih je nešto manje od $1 \%$ s posjedima od 10 do 30 ha te više od 30 ha.

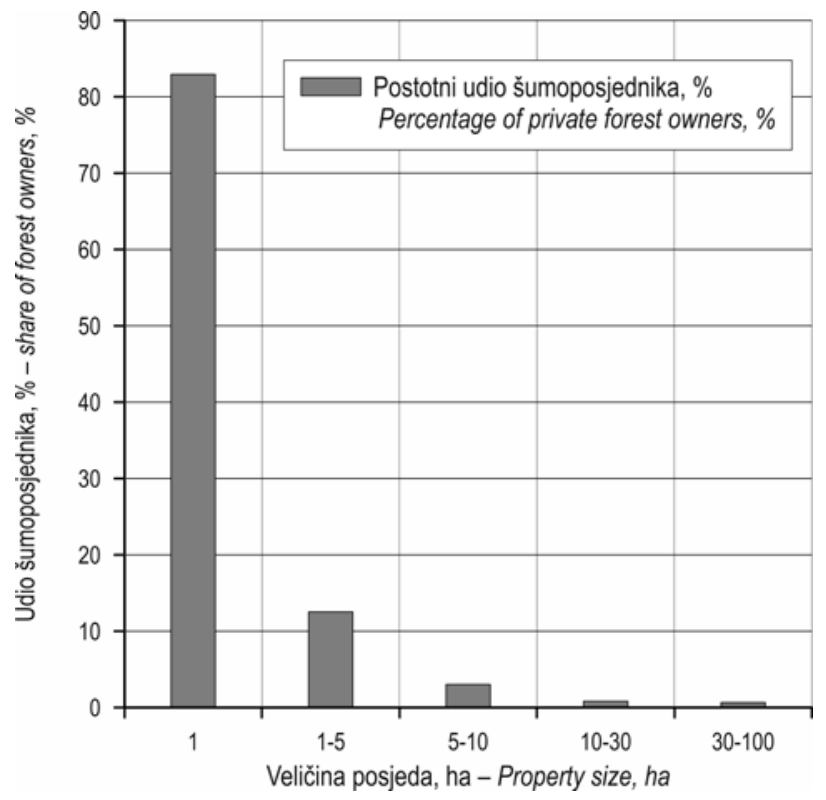

Slika 2. Postotak udjela posjednika u ovisnosti o veličini posjeda

Fig 2 Percentage of forest owners share depending on property size

Šumoposjedničke šume u Parku prirode Medvednica imaju drvnu zalihu od $3922635 \mathrm{~m}^{3}$, s ukupnim desetogodišnjim etatom od $728883 \mathrm{~m}^{3}$, što je veliko prirodno bogatstvo, ali i potencijal za bolje i 
angažiranije buduće gospodarenje (Tomašić 2018). Tako bi se šume dovele u optimalno i stabilno stanje, povećala bi se kvaliteta drvnih sortimenata, a posljedično i vrijednost, odnosno prihodi šumoposjednika.

\subsection{Pregled privatnih šuma po gospodarskim jedinicama - Overview of private forests by management units}

U okviru Parka prirode Medvednica nalaze se ove gospodarske jedinice. vrsta, utvrđena prisutnost ciljnih vrsta na temelju karte ciljnih vrsta)

$\Rightarrow$ usporedba sadašnjega i prijašnjega stanja ciljnih stanišnih tipova i identifikacija trendova

$\Rightarrow$ ciljevi i način postizanja ciljeva očuvanja za ciljne stanišne tipove i ciljne vrste zastupljene na šumskom zemljištu gospodarske jedinice obuhvaćenih ekološkom mrežom (ciljevi i mjere očuvanja područja ekološke mreže, način postizanja ciljeva očuvanja područja ekološke mreže s pokazateljima provedbe aktivnosti, analiza utjecaja

Tablica 3. Osnovni podaci o gospodarskim jedinicama u Parku prirode Medvednica

Table 3 Basic data of management units in Medvednica Nature Park

\begin{tabular}{|c|c|c|c|c|c|}
\hline $\begin{array}{c}\text { Gospodarska jedinica } \\
\text { Management unit }\end{array}$ & $\begin{array}{c}\text { Površina, ha } \\
\text { Area, ha }\end{array}$ & $\begin{array}{c}\text { Drvna zaliha, } \mathrm{m}^{3} \\
\text { Wood stock, } \mathrm{m}^{3}\end{array}$ & $\begin{array}{c}\text { Broj šumoposjednika } \\
\text { Number of private } \\
\text { forest owners }\end{array}$ & $\begin{array}{c}\text { Prosječna površina po } \\
\text { šumoposjedniku, ha } \\
\text { Awerage area per forest owner, ha }\end{array}$ & $\begin{array}{c}\text { Drvna zaliha, } \mathrm{m}^{3} / \mathrm{ha} \\
\text { Wood stock, } \mathrm{m}^{3} / \mathrm{ha}\end{array}$ \\
\hline Planina-Glavnica & 2193,53 & 619086 & - & - & 284,00 \\
\hline Gornja Bistra-Jakovlje & 1115,53 & 252979 & 2599 & 0,52 & 226,78 \\
\hline Bistransko podgorje & 1087,60 & 279343 & 2069 & 0,50 & 256,84 \\
\hline Čučerje-Šašinovec & 2490,59 & 698981 & 6337 & 0,57 & 286,72 \\
\hline Gora-Kulmerica & 230,66 & 90113 & 403 & 0,52 & 390,34 \\
\hline Humsko Prigorje & 1156,43 & 278019 & 2284 & 0,43 & 240,41 \\
\hline Selnica-Žitomir & 2545,34 & 635944 & 5872 & 0,37 & 249,85 \\
\hline Stubička Slatina-Pustodol & 1859,42 & 422604 & 4969 & 0,40 & 227,28 \\
\hline Stubičko prigorje & 683,37 & 153090 & 1712 & 3247 & 224,02 \\
\hline Zagreb-Medvednica zapad & 1006,92 & 218468 & 5003 & 0,31 & 216,97 \\
\hline Zagreb-Medvednica & 1179,7 & 274008 & & & 232,27 \\
\hline
\end{tabular}

Gospodarske jedinice koje se nalaze u Parku prirode Medvednica i području koje obuhvaća Natura 2000, u Programu gospodarenja gospodarskom jedinicom s planom upravljanja područjem ekološke mreže imaju detaljne smjernice i obveze vezane uz provedbu prakse gospodarenja kako je to propisano uvjetima zaštite prirode. Prema Pravilniku o uređivanju šuma (NN 97/2018) važeći program gospodarenja mora sadržavati ovo:

$\Rightarrow$ popis područja ekološke mreže

$\Rightarrow$ ciljne vrste i ciljni stanišni tipovi područja ekološke mreže

$\Rightarrow$ analiza sadašnjega stanja ciljnih stanišnih tipova (površina, dobna struktura za jednodobne šume, debljinska struktura za preborne i raznodobne šume, mrtvo drvo, stojeće i ležeće, zdravstveno stanje, negativan utjecaj i ugroze na ciljni stanišni tip)

$\Rightarrow$ analiza sadašnjega stanja ciljnih vrsta (ekološki zahtjevi svih ciljnih vrsta, analiza staništa ciljnih planiranih aktivnosti na ciljeve očuvanja i cjelovitost područja ekološke mreže)

$\Rightarrow$ za programe gospodarenja gospodarskom jedinicom s planom upravljanja područjem ekološke mreže osim karata koje se rade za osnovu gospodarenja izrađuju se još i karta stanišnih tipova IV. razine sukladno Nacionalnoj klasifikaciji staništa, karta ciljnih stanišnih tipova područja ekološke mreže, karta ciljnih vrsta područja ekološke mreže.

Smjernice izdaje nadležno ministarstvo te propisuje da su sve pravne i fizičke osobe koje gospodare prirodnim dobrima obvezne uskladiti planove gospodarenja prirodnim dobrima s odredbama Zakona o zaštiti prirode prilikom njihove obnove ili prve izmjene i dopune. Ključni uvjeti zaštite prirode za postojeće gospodarske jedinice jesu:

$\Rightarrow$ Program gospodarenja šumama šumoposjednika uskladiti sa zakonskim i podzakonskim akti- 
ma te međunarodnim konvencijama; dio odjela Uređajnoga zapisnika koji ulaze unutar granice Parka prirode Medvednica potrebno je uskladiti s Pravilnikom o unutarnjem redu u Parku prirode Medvednica

$\Rightarrow$ obaviti prostornu podjelu šuma i šumskoga zemljišta koja obuhvaća obilježbu na terenu i ucrtavanje na pregledne karte gospodarske jedinice (ucrtati granicu Parka prirode Medvednica)

$\Rightarrow$ očuvanje travnjačkih površina

$\Rightarrow$ radove pošumljavanja (popunjavanja), gdje to dopuštaju uvjeti staništa, obavljati upotrebom autohtonih vrsta ovoga područja, postojeće kulture (nasade) alohtonih vrsta postupno prevoditi $\mathrm{u}$ prirodne autohtone šumske zajednice ovoga područja

$\Rightarrow$ zabrana izvlačenja drva vodotocima te ostavljanja trupaca ili granja u njima, a nakon sječe i izvlačenja obvezno sanirati okoliš uz šumske prometnice, planinarske staze itd.

$\Rightarrow$ pri gradnji novih šumskih cesta ili protupožarnih prosjeka s elementima šumske ceste unutar područja ekološke mreže ili ako njihova gradnja može imati značajan negativan utjecaj na ciljeve očuvanja i cjelovitosti područja ekološke mreže, potrebno je provesti postupak ocjene prihvatljivosti zahvata na ekološku mrežu

$\Rightarrow$ voditi obrazac o opažanju ugroženih i strogo zaštićenih vrsta i ciljnih vrsta područja ekološke mreže Republike Hrvatske

$\Rightarrow$ pri pridobivanju drva potrebno je ravnomjerno po cijeloj površini na nekoliko hektara ostavljati 2 - 3 suha stabla ili stabla s dupljama i stabla voćkarica.

Kako bi se ispunilo očuvanje ekološke ravnoteže šumskoga ekosustava, potrebno je vođenje brige o svim čimbenicima ekosustava uz integralnu zaštitu šuma preventivnim i represivnim metodama zaštite. Navedene mjere uključuju podizanje i podržavanje mješovitih sastojina, štićenje korisnih životinja, sprečavanje nastanka šumskih požara te organizaciju čuvarske službe. Za ostvarivanje tih aktivnosti potrebno je posebnu pažnju posvetiti informiranju i osvješćivanju, udruživanju i okrupnjavanju te edukaciji privatnih šumoposjednika. Njima bi se trebali rješavati poznati i ključni problemi $u$ privatnom šumovlasništvu Republike Hrvatske, kao što su upoznavanje dionika s pravima i obvezama, aktivno uključivanje $u$ gospodarenje šumama, sređivanje imovinskopravnih odnosa te informiranje šumoposjednika o gospodarenju u područjima pod zaštitom.

\section{Diskusija i zaključci-Discussion and conclusions}

Privatne šume prema podacima ŠGOP-a i Nacionalne inventure sudjeluju s $24 \%$ površine i $22 \%$ drvne zalihe, s prosječnom drvnom zalihom od 157 $\mathrm{m}^{3} /$ ha, te imaju značajan udjel gospodarski važnih vrsta. Promatrajući navedene površine i drvnu zalihu, šume su dominantan ekološki sustav u zaštićenim područjima u Republici Hrvatskoj, a posebice u kontinentalnim područjima. U Parku prirode Medvednica drvna je zaliha $257,77 \mathrm{~m}^{3} /$ ha uz prosječnu površinu posjeda od 0,46 ha po posjedniku.

Posljednjih deset godina povećano zanimanje za gospodarenje privatnim šumama zasigurno je rezultirao i većom dinamikom u zaštićenim područjima. Pritom valja znati kako je gospodarenje šumama u pojedinim razinama kategorije zaštite prirode različito prema dopuštenim zahvatima u šumi, što dodatno komplicira gospodarenje privatnim šumama u zaštićenim područjima jer nisu svi parametri koji obilježavaju privatne šume primjenjivi. Pritom se misli na poticanje udruživanja, okrupnjavanje šumoposjeda te upisivanje $\mathrm{u}$ Upisnik. Kao primjer može se navesti činjenica da je korist od proglašavanja zaštite $u$ određenom području podizanje vrijednosti nekretnina pa to, uz ograničenost gospodarenja šumama u određenim kategorijama zaštite prirode, uzrokuje manju zainteresiranost za mogućim okrupnjavanjem šumoposjeda.

U ovom je radu kao primjer uzet Park prirode Medvednica u kojem su dopuštene gospodarske aktivnosti, međutim čitavo je područje uključeno u ekološku mrežu Natura 2000 čije očuvanje i upravljanje zahtijeva provedbu velikoga broja specificiranih mjera, a gospodarenje šumama visoku usklađenost s ekološkim zahtjevima.

Zaključno se može reći da su svi programi gospodarenja gospodarskom jedinicom s planom upravljanja područjem ekološke mreže za primjer Parka usklađeni s uvjetima zaštite prirode te ih se svi dionici moraju pridržavati. Jasni uvjeti nailaze na nepridržavanje zbog neriješenih imovinskopravnih odnosa, slabe suradnje šumoposjednika i savjetodavne službe te slaboga provođenja nadzora nadležnih inspekcija. Potrebno je educirati privatne šumoposjednike organiziranjem radionica $i$ terenskih demonstracija kako bi što bolje izmijenili iskustva. Posebno je bitno educirati šumoposjednike o korištenju sporednih šumskih proizvoda te o mogućem stvaranju njihove dodane vrijednosti. Ključ boljega gospodarenja leži i u poboljšanju odnosa dionika na relaciji Javne ustanove, Hrvatske poljo- 
privredno-šumarske savjetodavne službe i udruga privatnih šumovlasnika.

\section{Literatura - References}

Bakarić, M., 2018: Unaprjeđenje gospodarenja privatnim šumama u Republici Hrvatskoj modeliranjem poduzetničkih pothvata. Doktorski rad, Šumarski fakultet Sveučilišta u Zagrebu.

Hrvatske šume d. o. o., Služba za šume šumoposjednika: Udruge privatnih šumoposjednika. Pdf, str. 1 - 20.

Martinić, I., 2010: Upravljanje zaštićenim područjima prirode. Sveučilišni udžbenik, Šumarski fakultet Sveučilišta u Zagrebu, 336 str.

Martinić, I., 2011: Biološka raznolikost u privatnim šumama, što je i kako je očuvati? Krapinsko-zagorska županija, Javna ustanova za upravljanje zaštićenim prirodnim vrijednostima na području Krapinsko-zagorske županije, 24 str.

Martinić, I., 2019: Bioraznolikost šuma u Nacionalnom parku Plitvička jezera. Edukacijski vodič, Javna ustanova Nacionalni park Plitvička jezera, 9 str.

Plan upravljanja Parkom prirode Medvednica. https:// www.pp-medvednica.hr/wp-content/uploads/2019/05/ Plan-upravljanja-Parka-prirode-Medvednica.pdf (Pristupljeno 13.10.2021.)
Posavec, S., K. Beljan 2012: Information analysis of management goals of private forest owners in Croatia. Informatologia, 45(3): 238-245

Pravilnik o uređivanju šuma. NN 97/2018. https://narodne-novine.nn.hr/clanci/ sluzbeni/2018_11_97_1875.html (Pristupljeno 27. 11. 2021.)

Šumskogospodarska osnova područja Republike Hrvatske 2016.-2025. https://poljoprivreda.gov.hr/istaknute-teme/sume-112/sumarstvo/sumskogospodarska-osnova-2016-2025/250 (Pristupljeno 15. 10. 2021.)

Teslak, K., M. Žunić, K. Beljan, J. Čavlović, 2018: Stanje i izazovi gospodarenja privatnim šumama u Hrvatskoj u postojećim ekološkim i sociološkim okolnostima. Šumarski list, 9-10: 459-471. doi:10.31298/sl.142.9-10.1

Tomašić, F., 2018: Specifičnosti gospodarenja privatnim šumama u Parku prirode Medvednica. Diplomski rad, Šumarski fakultet Sveučilišta u Zagrebu, 44 str.

Vodič kroz EU fondove za šumarski sektor. http://www. hkisdt.hr/podaci/2015/ostalo/HKISDT_Vodic_kroz_EU _fondove.pdf (Pristupljeno 19.10.2021.)

Zakon o šumama. NN 68/18. https://narodne-novine. nn.hr/clanci/sluzbeni/2018_07_68_1392.html (Pristupljeno 15.10 .2021 .)

Zakon o zaštiti prirode. NN 80/2013. https://narodne-novine.nn.hr/clanci/sluzbeni/2013_06_80_1658.html (Pristupljeno 13. 10. 2021.)

\section{Features of Private Forest Management in Protected Areas with Reference to Nature Park »Medvednica«}

The last decade has been marked by increased interest of private forest owners in managing their forest holdings due to changes in the wood market caused by a large share of state forests where the wood industry is turning to other sources of raw materials. Traditional private forest management implies the exploitation of wood mass, usually unplanned, with the degradation of forest habitats. Public institutions that manage individual protected areas are increasingly exposed to cooperation with all stakeholders in order to satisfy the wishes of all of them in accordance with international and national legislation. The introductory part of the paper presents the basic data on private forests and states the problems of forest management in protected areas. The central part of the paper lists the categories of nature protection and institutions intended for the operational management of private forests. The results of the paper provide an overview of the area of private forests and the number of forest owners with wood stock, as well as a list of management units within the Nature Park based on an overview of management programs. The final part shows the possible improvement of the management of private forests in protected areas.

Keywords: private forests, protected area, private forests owners, NATURA 2000 
Primljeno (Received): 29. 10. 2021.

Prihvaćeno (Accepted): 17. 11. 2021.
Adrese autorâ - Authors' addresses:

Dr. sc. Matija Bakarić*

e-adresa:mbakaric@sumfak.unizg.hr

Prof.dr.sc. Željko Zečić

e-adresa: zzecic@sumfak.unizg.hr

Doc. dr. sc. Karlo Beljan

e-adresa: kbeljan@sumfak.unizg.hr

Sveučilište u Zagrebu

Fakultet šumarstva i drvne tehnologije

Svetošimunska cesta 23

10000 Zagreb

HRVATSKA

Fran Tomašić, mag. ing. silv.

e-adresa: frtomasic@gmail.com

Trg Stjepana Radića 6

49000 Krapina

HRVATSKA

* Glavni autor - Corresponding author 